\title{
Municipal Solid Waste Generation, Composition, and Management: Manado City
}

\author{
Teddy Takaendengan \\ Institut Teknologi Bandung \\ Bandung, Indonesia
}

\author{
Tri Padmi \\ Institut Teknologi Bandung \\ Bandung, Indonesia
}

\author{
Emenda Sembiring \\ Institut Teknologi Bandung \\ Bandung, Indonesia
}

\author{
Enri Damanhuri \\ Institut Teknologi Bandung \\ Bandung, Indonesia
}

\begin{abstract}
This study is intended to identify the conditions of municipal solid waste generation, composition and management and waste transportation system in Manado City, the capital of North Sulawesi, Indonesia. Data collected throughout this study was the amount and characteristics of residential wastes, the types and the amounts of waste collecting sites, waste collector and transporter systems, and the amount of waste entering Sumompo Landfill. The determination of waste amounts and compositions used [1]. Data on demography and other supporting data have been collected from Manado City governmental offices. Data of locations and a number of waste collectors and transporters was also validated from field observations. With around of 414,116 inhabitants, the amount of wastes generated was $0.78 \mathrm{~kg} / \mathrm{capita} /$ day or equivalent to $2.49 \mathrm{litres} / \mathrm{capita} / \mathrm{day}$. The average daily waste generation was 227.22 tonnes/day. Furthermore, the composition of waste from residential areas was dominated by organics $(57 \%)$, followed by plastic $(20 \%)$ and papers $(16 \%)$. The number of temporary containers spread across the city of Manado was around $\mathbf{5 7 5}$ units, where most of them in the form of the non-static bin. In addition, the overall volume of the existing bins was $376.7 \mathrm{~m}^{3}$. The vehicle of waste collecting and transporting used was 53 units, consisting of several types of vehicles, with $240 \mathrm{~m}^{3}$ of total volume. The system of waste collecting and the routes of waste transportation in residential areas were managed by sub-district according to local sanitation offices directions.
\end{abstract}

Keywords-municipal solid waste; waste generation; composition; transportation system

\section{INTRODUCTION}

The condition of waste management in Indonesia, with ever-increasing population sizes and public consumption level, trigger the ever increasing waste volumes. This condition makes the needs for better and better waste management so that no significant issues, the waste related problem will occur. Waste management in Indonesia is the sole responsibility of each respective local government. Every city or district should manage their own waste by forming their own sanitation offices. Under Indonesia Regulation No. 32, 2009, it has been stipulated that waste-related problems are the responsibility of local government and every local government must administer waste handling systems, including final processing sites inadequate ways, and on certain conditions, must administer regional final processing sites. Some of the major cities in Indonesia outsource their waste management.
The main problem generally facing in waste management of each district or city is the availability of sites for final processing. Most of the local governments in Indonesia have no adequate land for final processing site, and even if it is available, then this site has considerable distance from the city. The acquisition of sites for temporary landfilling sites throughout their waste transport routes is very difficult, due to the limitations of limited lands and funds.

The rapid development of the city has increased amount of demand for transportation infrastructure, and this situation triggers traffic problems, as well as the impact on the further waste transport track and longer travel time. The cost required for the transport system will be even greater with the presence levies burdening waste management system. Costs required for transportation system will be higher and will create any other retributions that will make more burden on the waste management system.

\section{WASTE COLLECTION AND TRANSPORTATION}

The types of waste transfers/containers all over Manado were as follows:

- 349 spots of 15-20 litres collecting spots

- 21 spots of $2 \mathrm{~m}^{3}$ collecting spots

- $\quad 37$ units of $2 \mathrm{~m}^{3}$ trash bins

- 40 units of $1 \mathrm{~m}^{3}$ waste carriages.

- 17 units of 40-liter trash cans

- $\quad 76$ units of 20 litres trash bins, and

- $\quad 35$ units of $6 \mathrm{~m} 3$ containers

The majority of Manado city waste collection and transportation system used the direct individual system, and their patterns were as follow:

- Waste vehicles come from their pools and head directly to their waste transportation routes;

- Waste trucks stop on the sideway of every waste service delivery household, and the waste transportation officer will take their wastes and fill the trucks until they reach their full capacities; 
- After reaching their full capacities, these trucks will head directly to their processing sites or final disposal site;

- From this site, the vehicles will head back to their next service route until their final shift, then head back to their pools.

The transport waste was done by vehicles consisting of many types of vehicles, namely 20 units of arm-roll, 20 units of dump-trucks, ten units of small pick-up trucks, three units of wooden box trucks and two units of iron box truck (City Cleanliness Div. Manado, 2014).

The main tasks of these waste vehicles are daily transporting of city waste with an average of 2 - 3 trips a day and manned by a driver and five waste transporter workers. The operational hours varied from 00.00 in the midnight until $11.00 \mathrm{am}$, to be continued on $16.00-22.00 \mathrm{pm}$. Each transportation sortie has its specific waste transportation routes that were generally been divided (distributed) by sub-district. The selection of waste collecting and transportation is generally been determined by their own drivers based on their own experiences or by trial and error.

Based on field observation, the Manado city waste management system still has several weaknesses as follows:

- Frequent waste transport delays, creating smell bad environment over the area in vicinities of every final processing sites

- Limited capacities of transport vehicles and limited qualities of waste managers so that waste spill filled throughout the transportation routes from the temporary landfill to final processing sites.

- Slump and unhygienic conditions of final processing sites environment conditions.

\section{WASTE TRANSPORTED TO LANDFILL SITE}

The Sumompo final disposal site $(50,000 \mathrm{~m} 2)$ is located in Manado City. Until 2014, the filled site was $10,250 \mathrm{~m} 2$, and the unfilled area was $39,750 \mathrm{~m} 2$. The landfill site was around $80 \mathrm{~m}$ height, so that waste volume was around $3.18-\mathrm{mi} \mathrm{m} 3$. During 2007-2008, the handling of this site has been done by waste dumping and pilling at the higher part of the locations to flatten latterly. These arrangement has been continued to be implemented in a better way so that it became controlled sanitary landfill in 2009 - 2011. It was predicted that Sumompo landfill will still be operated until 30 years ahead. The Sumompo landfill site is also equipped with a weighbridge which began its operation in April 2014.

The waste entering the landfill site came from several existing sources, most of them from a residential area, which was transported by regular waste vehicles from Manado Sanitation and Parks Office (DKP). The other sources were originated from 3 existing markets, three shopping malls, and self-service shops, small business/industries, military sites and so on. Table 1 shows the waste transported to landfill site of Sumompo, and Figure 3 is the daily average each month. There was a decreasing trend, from 222.23 tonnes/day (April
2014) to 205.46 tonnes/day (July 2014). The daily average from all data (April 2014 to January 2015) was 227.22 /tonnes/day (with 22.07 tonnes/day of standard deviation).

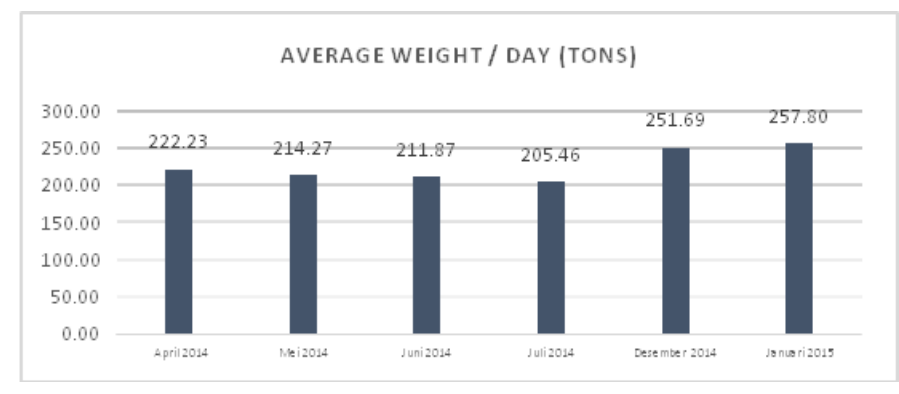

Fig. 1. Daily average of waste every month (tonne/day)

TABLE I. WASTE TRANSPORTED TO SUMOMPO LANDFILL SITE

\begin{tabular}{|l|l|l|l|l|l|}
\hline \multirow{2}{*}{ NO } & Sources & $\begin{array}{c}\text { Residential } \\
\text { (TPS) }\end{array}$ & Market & Mall & Others \\
\cline { 2 - 6 } & \multicolumn{1}{|c|}{ Month } & Weight (ton) & $\begin{array}{c}\text { Weight } \\
\text { (ton) }\end{array}$ & $\begin{array}{c}\text { Weight } \\
\text { (ton) }\end{array}$ & $\begin{array}{c}\text { Weight } \\
\text { (ton) }\end{array}$ \\
\hline 1 & April & 184.69 & 17.68 & 11.20 & 9.91 \\
2 & May & 176.93 & 17.29 & 11.18 & 9.44 \\
3 & June & 180.86 & 12.81 & 10.30 & 6.60 \\
4 & July & 175.23 & 15.38 & 9.24 & 5.61 \\
5 & December & 218.32 & 15.43 & 11.13 & 6.73 \\
6 & January & 227.96 & 15.68 & 9.44 & 4.72 \\
\hline & Sum & 1163.99 & 94.27 & 62.47 & 43.01 \\
& \% Average & 85.23 & 6.96 & 4.61 & 3.20 \\
\hline
\end{tabular}

The data obtained showed that the weight of the waste in April 2014 was 6451.33 tonnes, equivalent to $17,949 \mathrm{~m} 3$. The highest weight data occurs in January; it was 6964.76 tonnes. Based on the analysis, the total population served by the waste transport vehicles was $64 \%$ or 265,034 inhabitants, then the rate of waste generation, if it was calculated from waste transported from residential areas to final disposal, was 0.78 $\mathrm{kg} /$ capita/day.

\section{WASTE GENERATION AND COMPOSITION}

\section{A. Waste generation}

The important thing in the waste management strategy for each city is quantification and characteristics of municipal solid waste (MSW). Availability of data is needed to provide a rational basis for operations planning and management. In developed countries, the necessary data continually updated and available in the literature. In developing countries, the availability of data was minimal and insufficient. The physical composition is important to characterize and classify the MSW for appropriate management.

Municipal solid Waste, in general, can be classified as Organic, paper plastic, glass/ceramics, metal, wood, textile and others. In Indonesia, grouping waste composition is divided into 9 (nine) types according to [1] namely:1) food waste; 2) wood and garden waste; 3) paper and cardboard; 4) Textiles and textile products; 5) rubber and skin; 6); 7 plastic metal); 8) beaker and 9) Other inert materials. In classifying 
municipal solid waste, in Indonesia using the units \% volume wet, while the units commonly used is \% wet weight [2].

Research has been done in many countries, shows that the rate of waste generation varies greatly. In Indonesia, the variation rate of waste generation is generally influenced by 1) The number of population and its growth rate; 2) the fruit season; 3) way of life and mobility; 4) the handling food. Research that has been done, get the pace of urban waste generation for some countries in Asia are as follows:

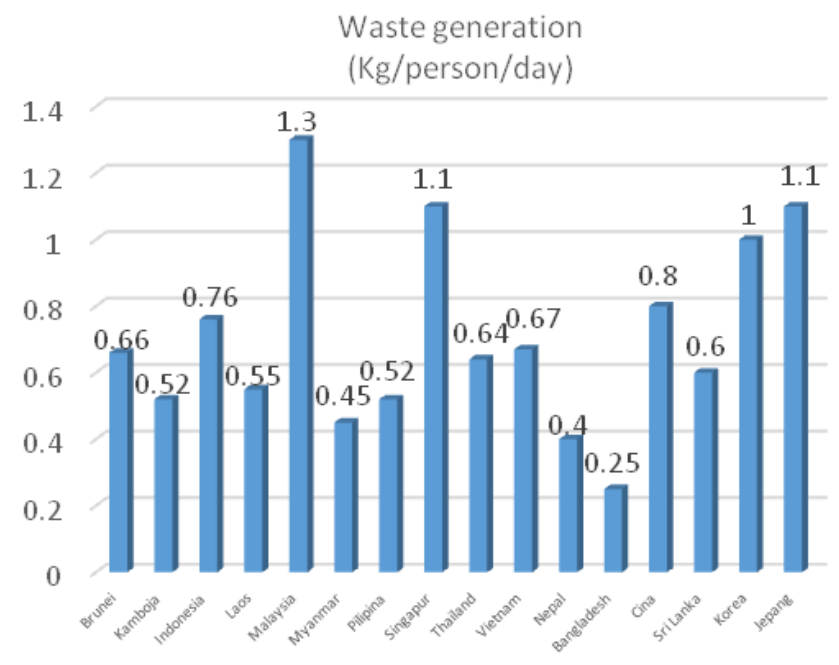

Fig. 2. Graph the rate of waste generation ( $\mathrm{Kg} / \mathrm{person} /$ day)

From the data, found that Malaysia has the highest rate of waste generation in Asia is equal to $1.3 \mathrm{~kg} / \mathrm{person} / \mathrm{day}$, followed by Singapore and Japan at $1.1 \mathrm{~kg} /$ person/day. Bangladesh possession of urban solid waste generation rate value is the smallest in the amount of $0.25 \mathrm{~kg} /$ person/day. While Indonesia itself has a value of urban solid waste generation rate of $0.76 \mathrm{~kg} /$ person/day [3].

For big cities in Indonesia, in can the data as follows:

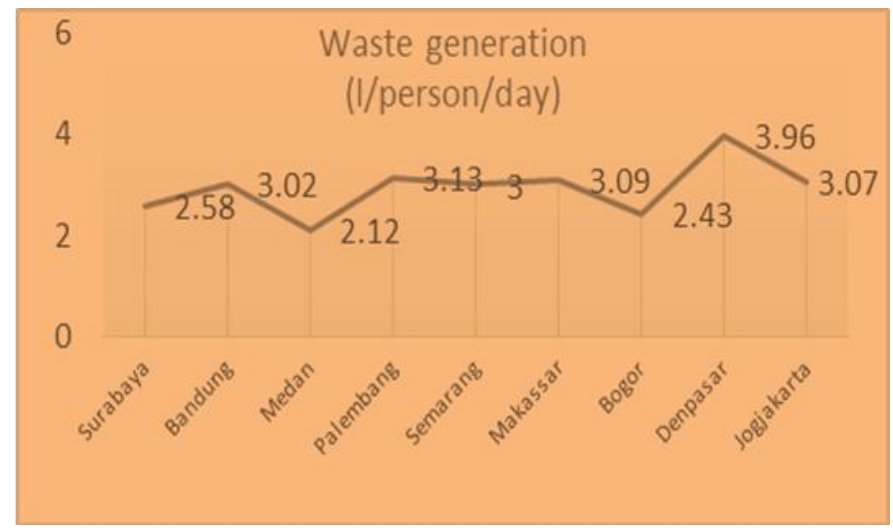

Fig. 3. Graph the rate of waste generation (1/person/day)

The graph above illustrates the value of the rate of urban waste generation in several cities in Indonesia. The highest value for the rate of waste generation is a city of Denpasar amounted to $3.96 \mathrm{l} / \mathrm{person} /$ day, while the city of Medan has the lowest score of $2.1 \mathrm{1} /$ person/day [4]. The value of urban waste generation rate for the city of Manado is equal to 0.78 $\mathrm{kg} /$ person/day or 2.49 1/person/day.

\section{B. Composition}

The data on waste generation and composition from residential sources were collected by direct sampling, using cluster sampling technique, based on their respective income level:

- Residential area 1: permanent housing areas with high-income levels, i.e., Liwas Permai elite residential area;

- Residential area II: semi-permanent housing areas with medium income level, i.e. on the vicinities of Politeknik Indah housing areas;

- Residential area III: non-permanent housing areas with lower income levels located on the beachside of Sindulang Dua village.

The sampling has been done during one consecutive week at the waste location sources. The waste composition in the city of Manado was presented in Figure 4. Compared to other cities in Indonesia, Surabaya city waste composition was dominated by organic wastes (68.5\%) Thabrew et al. (2009), while in Bandung city, this figure was 63.56. Some developing countries were also experiencing the similar figures, where the compositions of their waste were dominated by organic wastes, Bangladesh was 70\% [6], Pnom Penh was $87 \%$ and in Malaysia was 46\% 4) [6].

\section{Waste Composition}

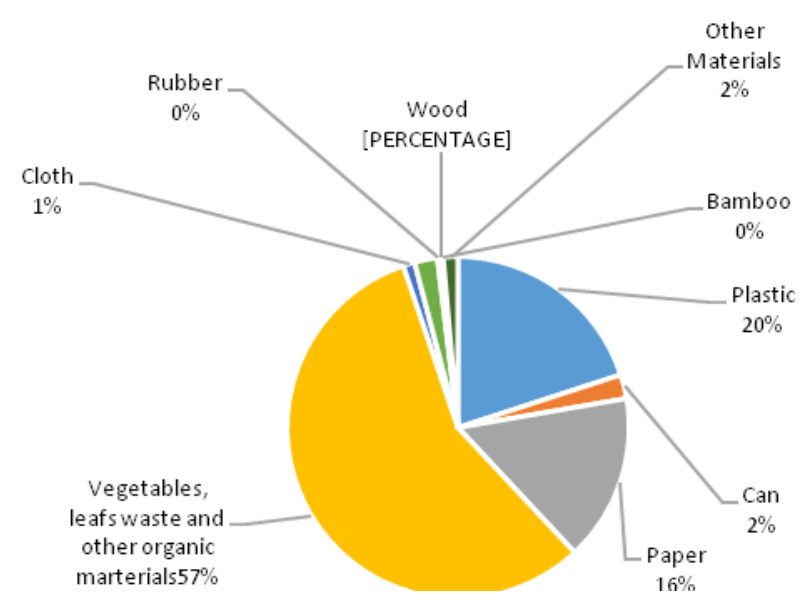

Fig. 4. Waste composition

\section{Acknowledgment}

The author would like to thank the Government of North Sulawesi province, especially the city of Manado, which has provided the data for this research. And also the Ministry of higher education, research and technology have been providing relief funds. 


\section{References}

[1] S. N. I. N. SNI, '19-3964-1994 Intake and Measurement Methods and Compositions Sample Urban Waste Generation', BSN.

[2] E. Damanhuri, W. Handoko, and T. Padmi, 'Municipal Solid Waste Management in Indonesia', in Municipal Solid Waste Management in Asia and the Pacific Islands, Springer, 2014, pp. 139-155.

[3] T. Karak, R. M. Bhagat, and P. Bhattacharyya, 'Critical reviews in environmental science and technology', Munic. solid waste Gener.

Compos. Manag. world Scenar., vol. 42, 2012.

[4] A. J. Morrissey and J. Browne, 'Waste management models and their application to sustainable waste management', Waste Manag., vol. 24, no. 3, pp. 297-308, 2004.

[5] L. Thabrew, A. Wiek, and R. Ries, 'Environmental decision making in multi-stakeholder contexts: applicability of life cycle thinking in development planning and implementation', J. Clean. Prod., vol. 17, no. 1, pp. 67-76, 2009.

[6] A. Pariatamby and M. Tanaka, 'Municipal solid waste management in Asia and the Pacific Islands', Environ. Sci. Springer, Singapore, 2014. 